\title{
Praticar corporais alternativas e seus significados
}

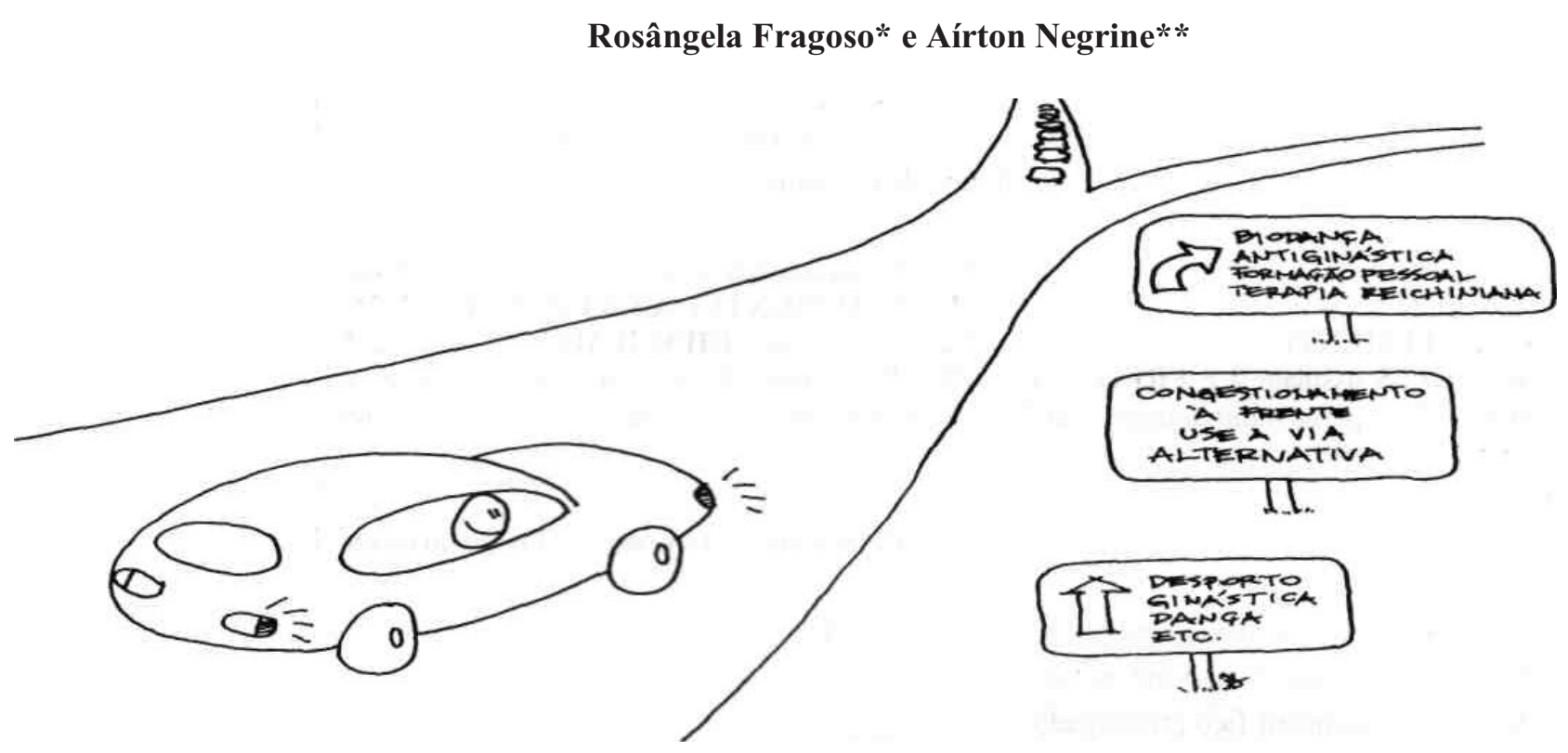

Este trabalho nasce de interesses convergentes de estudar práticas corporais alternativas, ou seja, aquelas que tradicionalmente não fazem parte dos currículos dos cursos de Educação Física e que pouco a pouco vão tendo cada vez mais adeptos. Surge como produto de um trabalho de iniciação científica financiado pelo CNPq e que se desenvolve no âmbito da Escola de Educação Física da Universidade Federal do Rio Grande do Sul.

A motivação inicial para a escolha da temática foi determinada pela compreensão que os movimentos corporais espontâneos exprimem: afetividade, emoção e sentimento. Estes aspectos, embora presentes em toda ação, nas atividades gímnicas-desportivas que predominam nos currículos dos cursos de licenciatura em Educação Física, pouco são valorizados como elementos de análise e avaliação do comportamento humano.
Movidos pela expectativa de realizar um exercício de investigação centrado em um assunto ainda muito pouco explorado pelos profissionais da Educação Física, foi que nos propomos a definir o problema que norteou o processo investigatório. $\mathrm{O}$ estudo se propôs a responder a seguinte indagação: "qual o significado e interpretação que é dado às práticas corporais alternativas a partir de diferentes perspectivas"?

A pergunta inicial derivou para o estudo das metodologias utilizadas e a compreensão do porquê que as pessoas buscam e como se sentem nestas práticas. Destacamos que as práticas corporais que estudamos, denominadas de "alternativas", dizem respeito às atividades corporais que se desenvolvem à margem da maioria dos currículos adotados pelas Escolas de Educação Física, que subjugadas ao desprezo científico, constróem sua fundamentação teórica fora dos parâmetros institucionais vigentes. 
As práticas corporais alternativas no foco do estudo englobam a Antiginástica, a Biodança, a Formação Pessoal e a Terapia Reichiana. Para estudá-las organizou-se o trabalho em três momentos. Primeiro nos detemos a fazer um rastreamento teórico e histórico de cada uma das práticas, tendo por base as bibliografias indicadas pelos professores e/ou facilitadores nas entrevistas realizadas inicialmente. Num segundo momento nos propomos a coletar informações sobre a dinâmica das sessões (início, meio e fim), tempo de duração e outras especificidades. Logo, a partir das entrevistas com os facilitadores, praticantes e das observações realizadas, procuramos apontar as motivações que levam as pessoas a buscar estas práticas corporais. No terceiro momento, situamos a discussão nos pontos convergentes e divergentes entre as referidas abordagens, sem remetê-las exatamente a uma confrontação teórica entre si, mas sim entendendo-as, como uma pequena amostra de um universo maior, e nos atendo em aspectos que os caracterizam. A partir destas informações introdutórias, analisaremos, em continuação, aspectos pertinentes ao marco teórico que sustenta as práticas corporais alternativas estudadas.

\section{ANTIGINÁSTICA}

Bertherat, descontente com a perspectiva mecanicista de corpo, busca uma terapia global que trate a pessoa como um todo. Desenvolve a Antiginástica, técnica que traz como "pano de fundo" uma abordagem e entendimento de homem, que tenta ir de encontro a esta necessidade.

Os exercícios clássicos, os esportes e a dança, segundo Bertherat, na maioria das vezes deformam o corpo, justamente porque usam-no de forma errônea e dissociada. Afirma a autora que os exercícios imbecilizam as pessoas, e que geralmente só servem para separar o corpo da cabeça. Isso não significa que defenda o fim desses trabalhos, mas propõe que, num primeiro momento, desenvolvam-se os movimentos naturais do corpo e que se explore amplamente suas possibilidades, para que este adquira inteligência muscular e sensorial e só mais tarde se trabalhe sobre movimentos mais específicos e precisos.

Bertherat sustenta que toda nossa his- tória de vida está impressa no corpo sob forma de tensão, rigidez, dor, fraqueza ou, ao contrário disso, sob linhas harmônicas e bem definidas. O que vai determinar as condições corporais são as riquezas das experiências e a forma como estas foram vividas. Quando tais experiências são dolorosas, a tendência é proteger-nos delas através de recalques, contrações musculares, retenção da respiração e assim por diante, que se expressam tanto sob a forma de deformações físicas como de distúrbios psicológicos.

Assim sendo, temos o que se denomina de "memória muscular", ou seja, os músculos guardam "todas as nossas experiências.... ao tocar o corpo de um ser, tem-se em mãos a sua vida e todo o seu passado" (Bertherat, 1985. p.85). Por exemplo, se uma criança vive uma situação familiar muito difícil e que não pode abandonar, organizará sua musculatura, responsável pela sua partida, de tal forma que paralisa-a, negando então sua vontade de ir-se e, assim, "pela vida afora, a criança guardará a sensação e o sentimento - talvez indizível - de estar restringida, de ser testemunha forçada de cenas a que não deseja assistir" (p.94) e que mais tarde, quando adulto, traduzir-se-á em "imobilidade, em todos os sentidos da palavra" (p.94), pois nossa organização muscular atende nossas necessidades.

Portanto, entende que nosso corpo é muito mais do que cabeça, costas, braços, pernas, ele é "nós" com tudo o que isso implica, sentimentos, pensamentos, história, cultura, reunidos e impressos em cada célula que a constitui. "Por isso tomar consciência do próprio corpo é ter acesso ao ser inteiro" (Bertherat, 1986. p. 14).

Entretanto, a autora (1985) questiona o que vem a ser afinal esse conscientizar o corpo, e sugere que o mais correto talvez seja dizer "tomada da consciência", pois para tomar consciência do corpo e torná-lo mais flexível, requer simultaneamente uma tomada de consciência e maior flexibilidade de comportamento, visto que um decorre do outro.

Sendo assim, Bertherat chama a atenção para aqueles pacientes que, pensando que querem curar-se, lhe procuram na verdade para ficar como estão, preferindo um trabalho que apenas lhe garantam a manutenção do seu

\section{"Qualquer passagem de um modo de ser para outro implica necessariamente o ato simbólico de morrer. É preciso morrer para a condição anterior a fim de renascer num estado novo ..." (Eliade, citado por Bertherat, 1980. p.38).}


"desequilíbrio habitual". Para muitas destas pessoas o corpo só existe à medida que lhes causa dor e o simples alívio é entendido como saúde. Acredita-se que isso ocorra devido ao fato de que

"qualquer passagem de um modo de ser para outro implica necessariamente o ato simbólico de morrer. É preciso morrer para a condição anterior a fim de renascer num estado novo ..." (Eliade, citado por Bertherat, 1980. p.38).

No livro As estações do corpo (1985), a autora faz um paralelo entre as estações do ano e as estações do corpo. Este tem estações para o repouso, para o movimento, para a cura, etc. Entretanto, é incrível como o homem viola seus próprios ritmos, solicitando-se além do que pode ou necessita, desrespeitando todas as pulsões internas, seus movimentos involuntários e tudo mais que o sistema nervoso administra.

Também destaca o fato de que as pesBertherat é levar a aprendizagem do bem-estar, a perceber o que é "sentir-se bem", a movimentar-se sem entraves, a liberar-se das inibições que impedem de agir, a fim de que essa nova experiência entre na memória corporal e que a pessoa, a par disso, consiga restabelecer sozinha o próprio equilibrio. soas têm uma visão muito fragmentada de seu corpo e conseqüentemente de si, entretanto isto não é característica apenas de leigos, também alguns especialistas na área de saúde \% médicos, fisioterapeutas, professores de educação física .... \% consideram o corpo segmento por segmento. Nesse sentido questiona se isso é decorrência de uma formação profissional dissociativa ou de uma percepção fragmentada com a qual estes vivem o próprio corpo. $\mathrm{O}$ objetivo de Bertherat é levar a aprendizagem do bem-estar, a perceber o que é "sentir-se bem", a movimentar-se sem entraves, a liberarse das inibições que impedem de agir, a fim de que essa nova experiência entre na memória corporal e que a pessoa, a par disso, consiga
1. são em maior quantidade numérica;

2. são músculos maiores em volume e espessura;

3. são poliarticulares $97 \%$ deles;

4. estão constituídos de uma forma tal que "constituem uma cadeia contínua do alto do crânio à ponta dos pés, ao passo que os músculos do queixo ao tórax formam uma linha interrompida" (p. 9).

Sendo assim, diz que quando propõe um movimento simples como: de pé, com pés juntos e paralelos, flexione a coluna à frente, deixando a cabeça pender e indo com as mãos até o chão, poucos conseguem fazê-lo, e aqueles que conseguem muitas vezes o fazem forçando as articulações dos joelhos e rotando-os para dentro. Isso ocorre devido ao encurtamento da musculatura posterior que, ao não acompanhar o movimento, deformam o corpo (Bertherat, 1986).

Muitas vezes apontam como causa das
deformações a musculatura anterior, e a explirestabelecer sozinha o próprio equilíbrio.

É, portanto, a partir dessa ótica e desses questionamentos que Bertherat desenvolve a antiginástica, tomando apoio no método desenvolvido por Françóise Mèziéres.

Antes de entrarmos na metodologia da Antiginástica, faz-se necessário apresentar alguns conceitos desenvolvidos por Françóise Mèziéres, base do trabalho criado por Bertherat. Mèziéres postula que as contrações crônicas da musculatura posterior são as causas de todas as deformações morfológicas, "exceto as fraturas e algumas deformações congênitas" (Mèziéres, citado por Bertherat, 1986., p.123). A razão disso é que os músculos posteriores: cação que encontra para isso é que esta vemos e temos consciência, enquanto a posterior não, fica obscura, inconsciente, impedindo-nos que percebamos ser ela a verdadeira origem do problema. Afinal, para Bertherat, $80 \%$ de nossas percepções sensoriais são visuais. Se os músculos da região anterior do corpo são fracos e flácidos é porque os músculos posteriores são muito fortes e contraturados. Quanto aos primeiros, não é necessário fazer nada, pois são esses últimos que precisam ser soltos, alongados, para que possibilitem que a cadeia anterior se reorganize. De tal forma que, ao se soltar a musculatura posterior mudam-se os movimentos, estes tornam-se fluentes e coesos.

Afinal, o princípio fundamental dentro desta perspectiva é que o corpo sadio deve ter ombros, clavículas, costelas, omoplatas, ilíacos, joelhos e pés simétricos. Deve-se ter facilidade em manter-se em pé; de flexão do tronco, quando os joelhos não devem rotar para dentro e assim por diante. Caso algum desvio nesse sentido ocorra, entende que há uma deformação corporal originada pelo excesso de força da musculatura posterior.

Postula ainda que, sentimentos como raiva e medo, dos quais não chegamos a ter consciência, ficam atrelados a nossa musculatura, sendo que boa parte vai mais especificamente para a musculatura posterior. 
A musculatura posterior "está sempre pronta a se contrair. Contrair-se é coisa simples para um tecido contrátil por natureza"(1989, p.38), razão pela qual é muito mais importante relaxar a musculatura posterior do que contrair e fortalecer a anterior. Sendo assim, o objetivo do trabalho é soltar a musculatura, a posterior em especial, com movimentos suaves, que são experimentados primeiramente pelo próprio professor que os aplicará, pois Ehrenfriend (citado por Bertherat, 1986) diz que é necessário compreender esses movimentos com o próprio corpo para só então recomendá-lo a outros.

Bertherat (1986), diz que entrevista individualmente cada aluno em suas aulas, para ter uma idéia de como são e o que buscam, consciente ou inconscientemente. Quanto aos movimentos realizados nesta prática, o professor não os demonstra, por entender que a repetição mecânica de um movimento é inútil, pois logo que "a atenção se distrai o corpo retoma seus velhos hábitos" (p.49). Nesse sentido, aponta a respiração como elemento importante, não devendo ser contida, uma vez que, contendo-a, contemos também nossas emoções e sensações. Sustenta que desde pequenos cortamos a respiração quando temos medo, ou quando nos machucamos e que mais tarde prendemos a respiração quando tentamos não chorar ou gritar.

Com o tempo isso vai se tornando crônico, e é necessário que o corpo reencontre o ritmo respiratório que lhe é próprio, liberando a respiração sem treiná-la. Acredita que se esta apresenta problemas, é porque a musculatura posterior precisa ser relaxada. Ensina que o professor deve ir falando quais os movimentos que deseja que sejam feitos e, por sua parte, os alunos realizam e vivenciam de acordo com suas percepções. Caso tenham muita dificuldade em realizá-los, o professor deve ajudá-los utilizando a palavra, para que cheguem por si mesmos a descoberta sensorial de seu próprio corpo.

A essência desse trabalho está no respeito pelo ser humano, no objetivo de proporcionar que este descubra suas possibilidades, que alcance mais inteligência e independência.

Outro ponto destacado, é o de sempre trabalhar um lado do corpo de cada vez, quando um lado está bem e sadio o outro entra em sintonia com este. Neste sentido, sempre ao citar trabalhos em seus livros, Bertherat propõe que se movimente primeiro o lado direito e depois o esquerdo. O mesmo cuidado esteve presente nas aulas práticas de antiginástica observadas durante $\mathrm{o}$ processo investigatório.

Embora Bertherat tenha algumas reservas no que se refere às terapias psicocorporais, por entendê-las breve e de muito impacto, entende ser correto que se desenvolvam trabalhos onde a pessoa possa expressar-se verbal e corporalmente. Ao longo de sua experiência, incorpora a palavra na metodologia da antiginástica. Entretanto, sustenta que a fala não é obrigatória, porque palavras soltas ditas por alguém podem atingir outra pessoa, tendo-lhe um forte significado. Tampouco faz interpretações ou análises do comportamento e descobertas do outro.

Bertherat cita um trabalho de Feldenkrais que usa em suas aulas: começa-se pelo lado direito, fazendo movimentos que aumentem a amplitude de todas as articulações. Depois visualiza-se os mesmos movimentos do lado esquerdo. Isso feito, passa-se a executar efetivamente os movimentos e percebe-se uma facilidade para fazê-lo muito maior do que fora do lado direito.

Bertherat (1989), quando fala da análise diagnostica e tratamento através da antiginástica, sugere que há três locais em que a musculatura posterior mais se encurta: na nuca, região lombar e parte posterior do joelho, e para verificar as condições dessa musculatura, apresenta alguns testes, que pensamos ser desnecessário descrevê-los, uma vez que nas suas obras estes aspectos estão muito bem explicados.

\section{BIODANÇA}

Com o intuito de promover uma transformação no curso da evolução humana, Rolando Toro Araneda criou a Biodança, uma pedagogia de vida baseada numa metodologia de trabalho essencialmente vivencial em que a emoção e o contato advindos da interação com o outro no grupo proporcionam ao homem reconstruir sua individualidade, base para a criação de uma sociedade sadia.

\section{A musculatura \\ posterior "está sempre pronta a se contrair. Contrair- se é coisa simples para um tecido contrátil por natureza" 1989 , p.38), razão pela qual é muito mais importante relaxar a musculatura posterior do que contrair e fortale- cer a anterior.}


Biodança $^{3 / 4}$ "Dança da vida" 3/4 é, segundo seu proponente, um novo estilo de vida onde se promove o desenvolvimento da identidade através do trabalho sobre as cinco potencialidades genéticas: vitalidade, criatividade, afetividade, sexualidade e transcendência. Estes são os cinco eixos na construção da identidade que Toro propõe. Sendo assim, desenvolvem-se exercícios específicos de vivência e expressão dos aspectos saudáveis das relações humanas, onde o amor é seu pólo norteador.

Entretanto, antes de falarmos um pouco mais sobre a Biodança, queremos deixar claro que não é farta a bibliografia específica. Este trabalho está ancorado numa coletânea de textos escritos por Toro e organizados em forma de "Tomo de Biodança" por Sérgio Góis, que é inclusive o material teórico básico para o curso de formação em facilitadores de Biodança no Brasil.

Rolando Toro, médico e psiquiatra, a partir de seus estudos sobre antropologia cultural, em que observou o quanto os povos primitivos valiam-se de rituais com dança e música para tratar seus doentes. Dá início, em 1965, a trabalhos de dança com pacientes psiquiátricos no Hospital Psiquiátrico do Chile, dos quais obteve as seguintes impressões:

"Observei que certas músicas tinham efeitos contraproducentes, pois os conduziam com facilidade a estados de transe. Nesses casos, as alucinações e delírios acentuaram-se e podiam durar vários dias. Indubitavelmente, os enfermos que, por definição, têm uma identidade mal integrada, dissociavam-se ainda mais quando realizavam certos tipos de movimento" (Toro, 1991. p.5-6).

Selecionou, a partir daí, músicas e danças que pudessem reforçar a identidade. Propôs também exercícios de contato para dar limite corporal e coesão. $\mathrm{O}$ resultado foi claro: muitos enfermos elevaram seu juízo de realidade, diminuíram as alucinações e aumentaram a comunicação. Ficou assim desenhado o primeiro eixo para o modelo teórico que, com o tempo, foi-se aperfeiçoando.

A partir disso, Toro desenvolveu a Psicodança que tinha como modelo operatório dois eixos: (1) identidade - transe e (2) diferenciação - integração. Em seguida cria, também os primeiros conceitos da teoria da vivência e da protovivência que serão estudados, mais adiante, neste trabalho.

Em 1978 a Psicodança, norteada por uma visão antropocêntrica - homem como centro do universo, meta primeira a ser atendida - muda seu foco para uma perspectiva biocêntrica - vida como centro do universo — passando a denominar-se Biodança. Nesta nova visão, o ser humano é importante, mas na medida que é integrante desta vida, que participa e interage nela em sua forma maior — biocósmica.

Devido ao amplo alcance deste método, capaz de modificar desde a homeostase orgânica até o estilo de vida, Toro chega a palavra Biodança, por conter o termo grego "Bio" ${ }^{3 / 4}$ vida ${ }^{3 / 4}$ e dança que, segundo ele, em francês significa "movimento integrado, pleno de sentido".

É marcante nos textos de Toro sua forte crítica às atuais formas de educação que, no seu entendimento, não desenvolvem as potencialidades do homem, seus afetos, seus vínculos, sua consciência ecológica .... Aponta nossa civilização como caracterizada por uma cultura que promove dissociação e alienação, como negadora de nossa animalidade, e repressora de nossos instintos. E preciso romper com a dicotomia de nossas percepções, perder o medo aos próprios instintos, pois retomá-los significa resgatar o ser humano na sua integridade.

Toro propõe que se pense novamente em amor, liberdade e transcendência de forma con creta, como experiência corporal, pois a falta de amor gera "uma situação biológica insupor tável" (p. 63), afinal o homem sempre buscou isso sob forma de ideologias, religiões, filoso fias ..... É através dele que se alcança estrutu ra e unidade para a verdadeira independência. Entende que para uma autêntica mudança so cial é preciso assumir o amor que temos den tro de nós, abandonar o corpo rígido, preconceituoso, sustenta que:

\footnotetext{
"Não basta liberar o homem da miséria econômica. Também é necessário liberá-lo de sua miséria afetiva e sexual, de sua pobreza criativa, de sua incapacidade para desfrutar o prazer de viver" (Toro,1991. p.93).
}

É urgente unificar o indivíduo, entender que seu corpo é a expressão de toda a sua existência, que corpo e alma são dois aspectos 
de uma mesma realidade. Um dos pressupostos da Biodança objetiva viver essa totalidade de forma intensa. Um revolucionário sem es-

tas características nada tem de realmente novo para oferecer, é impossível fazer transformações sem questionar sua própria conduta.

Entretanto, quando a Biodança propõe que se cultive $o$ amor, não quer com isso que

se perca a capacidade de luta, muito pelo con-trário, junto ao prazer de viver desenvolvem-se trabalhos que potencializam a coragem e o ímpeto de viver, de atrever-se e de tirar as mordaças que nós mesmos nos impomos.

A Biodança traz em sua essência uma proposta de um novo estilo de vida, onde a metodologia utilizada é a vivência em grupo, com música, dança e canto. É enfatizado o aqui-agora, ou seja, incentiva-se que se viva o momento intensamente, que se esteja presente no instante vivido. Na Biodança os participantes não são considerados "pacientes", mas agentes de sua cura e da cura dos demais do grupo. A relação paciente - terapeuta não existe, o que se tem é uma relação "amigo-amigo", onde cada um cura os demais com seu amor.

O coordenador de Biodança é uma pessoa como as outras, também em busca de desenvolvimento que, para assumir esse papel, deve ter como pré-requisito básico: ser profundamente afetivo, ter vocação humanista, desejar ajudar ao próximo, espírito aberto ao prazer de viver, ser sincero e corajoso.

Não há elaboração verbal das aulas, por entender-se que a melhor elaboração é feita quando assume-se as vivências com tudo o que esta suscite pois, como diz Toro, os sentimentos começam a sedimentar-se a nível orgânico, sem a intervenção de decisões mentais, pois estas, no fundo, são expressões da tirania do mundo exterior.

\section{A FORMAÇÃO PESSOAL}

A formação pessoal, como prática corporal alternativa emerge a partir das escolas de Formação de Formadores em Psicomotricidade, proposta por Lapierre e Aucouturier, vindo a se constituir na terceira via de formação, considerando a primeira uma formação teórica, e a segunda uma formação

pedagógica construída na ação do adulto com a criança. A Formação pessoal se propõe a ser um espaço em que o adulto em formação reflita sua própria conduta, numa atitude introspectiva, perceba seus desejos, limites, expectativas e decepções nas relações com os outros, com os objetos e com o espaço que lhe rodeia. Local onde, ao profissional em formação, será oportunizado vivências corporais na qual encontre prazer de movimento, disponibilidade corporal e facilidade de comunicação.

Parte-se do entendimento de que, antes de trabalhar com o outro, é necessário que trabalhe consigo mesmo, e isso se dará através da corporeidade, oportunizando que descubra uma nova via de impressão e expressão:

"É esta formação que vai permitir que o adulto
passe a ter mais disponibilidade corporal,
conheça melhor suas limitações e ao mesmo
tempo possa refletir sobre elas. Este autoconhe-
cimento permite o desbloqueio de certas
resistências, permite uma dimensão mais real
das limitações de cada indivíduo frente a
diferentes situações e, conseqüentemente,
prepara o profissional para ter uma 'postura de
escuta' em relação à criança, melhorando assim
a compreensão e seu relacionamento com ela"
(Negrine,1994. p.2).

A operacionalização disso será feita de forma lúdica, para que, na fronteira de seus limites, o aluno vá ampliando sua disponibilidade e suas possibilidades num clima de permissividade, criatividade e interação.

A psicomotricidade, para quem não a conhece, nasce da investigação das problemáticas motoras e encontra "receptividade" entre os psicólogos, pedagogos e professores de educação física. Surge com um enfoque reeducativo e, posteriormente, apresenta-se sob dois outros enfoques: educacional e terapêutico.

Embora Lapierre e Aucouturier tenham inovado na formação dos psicomotricistas, publicando inclusive uma série de trabalhos juntos, durante a caminhada houve um distanciamento dialético na forma de entender a prática psicomotriz. Mas o que realmente nos interessa nesta reflexão é o ponto em que eles convergem. E esse ponto é proposta de incluir a formação pessoal como mais uma via de formação dos psicomotricistas.

\section{Para Lapierre e Aucouturier "o diálogo}

"Não basta

liberar o homem

da miséria

econômica.

Também é neces-

sário liberá-lo de

sua miséria

afetiva e sexual,

de sua pobreza

criativa, de sua

incapacidade

para desfrutar o

prazer de viver." 
corporal tônico é fundamental e sua qualidade vai influenciar todo o futuro da criança" (1984, p.12), pois dependerá das vivências motoras daí advindas a imagem que formará de seu eu corporal. O diálogo tônico tem sua origem nas relações primárias com a mãe, relação que pode ser privilegiada para alguns e com certas carências para outros.

\section{"É esta formação que vai permitir que o adulto passe a ter mais dispon ib ilidade corporal, conheça melhor suas limitações $e$ ao mesmo tempo possa refletir sobre elas. Este auto conhecimen- to permite o desbloqueio de certas resistências, permite uma dimensão mais real das limitações de cada indivíduo frente a diferentes situações $e$, conseqüentemente , prepara o profissional para ter uma 'postura de escuta' em relação à criança, melhorando assim a compreensão e seu relacionamento com ela."}

Portanto, a falta no corpo, do corpo do outro, gera o que denominam "fantasma ${ }^{1}$ original" que está ligado à ruptura fusional do nascimento e o desejo inconsciente de retorno a essa plenitude pré-natal. Como veremos, ao longo da vida, tentaremos suprir essa "falta do ser", essa "falta de ser".

Entretanto, o bebê terá de aceitar a separação e viver a frustração de não possuir o corpo do outro como local de prazer. Porém, isso só é possível através de substituições simbólicas, dentro de um "espaço fusional" que não é mais direto, ou seja, surgem mediadores dessa fusão, através de produções corporais gestos, olhar, voz, mímica — ou de objetos.

Quanto a esse objeto, ele passa a ser o substituto complementar de sua falta, é o que Winnicott denomina de "objeto transacional". Esse objeto é entendido como seu, ou seja, há uma transferência entre ser o objeto para ter o objeto.

Dentro deste contexto investe-se muito mais no desejo de ter (seja no sentido material, cultural ou intelectual) do que de ser, pois Lapierre e Aucouturier apontam esse último como muito mais abstrato, profundo e difícil de ser satisfeito. Esses dois desejos são diretamente proporcionais, pois na medida em que o segundo é insatisfeito procuramos mais compensações materiais.

Desde uma visão psicanalítica nos primeiros meses de vida, o bebê vive num estado de fusão não só com a mãe como com o mundo. Porém, Lapierre e Aucouturier dizem que a fusão é sempre perda da identidade e perderse no espaço é tão angustiante quanto perderse no outro, no entanto é necessário resistir a esse fantasma, e viver a entrega para constituir e tomar posse da própria identidade.

Ter claro o desejo fusional, o desejo de identidade e a fantasmática corporal daí advinda é imprescindível para compreendermos a proposta de Lapierre e Aucouturier no que se refere à formação pessoal. Esses autores defendem que, se pretendemos alcançar profundas mudanças na personalidade, é ao nível de corporeidade que se deve agir; os fantasmas serão percebidos através exclusivamente da situação vivencial e, conseqüentemente, faz-se necessário identificá-los e saber lidar com eles.

Sendo os fantasmas corporais inconscientes originais, propõem trabalhos que levam o sujeito a agir desvinculado de objetivos racionais, o que proporciona a emergência dos fantasmas originais:

\footnotetext{
"a angústia só se soluciona quando o imaginário inconsciente pode ser simbolizado... O fantasma desmascarado e identificado, perde seu poder de perturbação emocional" (Lapierre e Aucouturier. 1984, p.65).
}

No que se refere ao corpo do terapeuta e/ou psicomotricista, durante os trabalhos com crianças, ele será o palco, na medida em que interage com elas.

\begin{abstract}
"O corpo do terapeuta deve ser revelador do que a criança não pode dizer, nem escrever, nem desenhar; fantasmas que ela exprime inconscientemente em seu modo de agir (Lapierre e Aucouturier, 1984. p.66).
\end{abstract}

Entretanto, para a devida eficiência desse processo, é necessário que o terapeuta tenha consciência: (1) do quão rápido a criança estabelecerá vínculo com ele e transferirá para esta relação todos seus fantasmas, desejos, angústias, medos, pois a partir desse entendimento o terapeuta colocará seu corpo à disposição da criança, não passivamente, mas ativo em contextualizar e possibilitar que exprima seus desejos num diálogo tônico; (2) ter consciência também de seus próprios fantasmas, de seus desejos inconscientes para com estas crianças, para que isso não interfira na relação que se estabelecerá entre eles.

Certamente sabem esses autores que trazer à consciência conteúdos inconscientes é tarefa muitas vezes árdua, porém fundamental para que possamos dominar, e não recalcar nossos impulsos, visto que a vida social só é possível graças a isso. Para tanto, propõem que ao terapeuta e psicomotricista seja oportunizado durante sua formação um espaço em 
que possa trocar com seus colegas, num grupo de controle, o que percebem de sua conduta para com as crianças, sua contratransferência e, naturalmente, suas próprias sensações e conjecturas enquanto trabalha propriamente com elas.

No entendimento de Lapierre e Aucouturier, assim como o psicanalista, que alcança sua formação através de sua própria análise, com o terapeuta psicomotricista não deveria ser diferente. A este, deve ser oferecido uma formação menos anatomofisiológica e mais analítico-perspectiva, que objetivará: tornar o reeducador consciente das induções de sua própria problemática corporal na sua relação com o outro; atenuar ou ultrapassar suas resistências tônicas de modo a ficar corporalmente disponível; tomar consciência de sua própria relação fantasmática com o mundo, com o espaço, com os objetos.

Já Negrine estende a formação pessoal, proposta por Lapierre e Aucouturier, para todos os profissionais que trabalham com pessoas. Ciente que toda a relação é transferenciai, não percebe coerência no fato de um profissional assumir seu papel sem ter passado por vivências que lhe tragam à consciência seus próprios fantasmas, para que possa lidar com estes e evitar que isso venha a interferir negativamente na sua relação com o outro.

\section{A TERAPIA REICHIANA}

Wilhem Reich (1897-1957), médico e psicanalista austríaco, desenvolveu a Orgonoterapia a partir das evidências que encontrou em suas observações clínicas sobre a unidade corpo/mente. A essência de sua contribuição deve-se ao fato de ter elaborado o que se pode considerar, segundo Trotta (1993), a mais abrangente e bem fundamentada metodologia de trabalho sobre a dinâmica biopsíquica das emoções.

"Na concepção reichiana o ser humano é uma unidade biopsíquica cujo funcionamento é expresso simultaneamente em emoções e funções fisiológicas. As contenções emocionais associadas aos impulsos instintos privados de satisfação cronificam-se perturbando o funcionamento orgânico e psicológico; sendo esta a origem de todas as patologias" (Trotta, 1993. P8).
A terapia reichiana entende o mal-estar físico e emocional como manifestações diferentes de uma mesma problemática, sendo que é através da emoção deflagrada e elaborada, que se restabelece o equilíbrio do sujeito como um todo.

A terapia reichiana, criada por Reich, nasceu a partir da Psicanálise. Em 1919, Reich apresenta um ensaio, que é alvo de muitos elogios no seminário de sexologia sobre "Conceitos da libido de Forel a Jung", no qual interpreta o conceito de libido de Freud, não como a libido dos pré-freudianos - que denotava o desejo consciente de atividade sexual - mas sim como a energia em si do instinto sexual.

É importante esclarecer que, excitação sexual-libido como Freud a chamou-não se restringe apenas a sentimentos e fantasias sexuais conscientes mas, como define Reich citado por Boadella, ela é a "energia viva" da Psicanálise. Afinal, se observarmos o prazer com que o bebê se entrega após a mamada, segundo Freud (ibid) não há como não nos remetermos à imagem da expressão de prazer referente ao ato sexual.

Entretanto, voltemos um pouco a 1895 , quando Freud havia proposto que o acúmulo da energia sexual não descarregada é a razão de algumas formas de neurose de angústia. Ocorre que nunca conseguiu ter claro o mecanismo que fazia com que as sensações sexuais se tornassem angústia. Com isso, progressivamente, Freud e seus colegas abandonaram a teoria inicial dos instintos (libido) em direção à psicologia do ego, enquanto Reich dedicouse a confirmar e desenvolver essa teoria e pesquisar em torno da questão de como a êxtase sexual poderia levar à produção de angústia, sendo que a solução para essas questões tornou-se a pedra fundamental de sua teoria econômico-sexual: a teoria do orgasmo.

Assim, em 1923, Reich apresenta o seu primeiro artigo sobre "A genitalidade do ponto de vista do prognóstico e da terapia psicanalítica", porém, tem combatida sua teoria de que, como Freud havia dito, realmente neurose e vida sexual normal são duas características incompatíveis em um mesmo indivíduo.

Da mesma forma, em 1924, depara-se

\section{" $A$ angústia só se soluciona quando o imaginário inconsciente pode ser simbolizado... O fantasma desmascarado e identificado, perde seu poder de perturbação emocional."}


com uma forte resistência por parte da sociedade psicanalítica, quando apresenta a teoria do orgasmo, pois a Psicanálise começava a deixar de lado a teoria da libido:

\begin{abstract}
"A Psicanálise e a economia sexual tomaram direções opostas, uma vez que a primeira passou a não dar atenção à quantidade emocional e a se concentrar cada vez mais nos conteúdos da vida psíquica e a se desenvolver em direção a uma psicologia das idéias; enquanto que o foco de Reich na quantidade de excitação deveria leválo ao campo da pesquisa da energia física" ( Boadella, 1985. p.19).
\end{abstract}

A teoria econômica-sexual desenvolvida por Reich, como ponto-chave de sua abordagem terapêutica, pretende abarcar um novo campo científico: a investigação da energia biopsíquica, sendo que o cerne dessa teoria é o fato de que a saúde psíquica depende da potência orgástica, da capacidade do indivíduo de entregar-se para o clímax do ato sexual natural e para o amor.

"O corpo do terapeuta deve ser revelador do que a criança não pode dizer, nem escrever, nem desenhar; fantasmas que ela exprime inconscientemente em seu modo de agir."
Avançando um pouco na análise dessa questão, Reich considera que o tema "sexualidade" atravessa outras áreas do conhecimento humano sofrendo influências do campo da Psicologia, Fisiologia, Biologia e Sociologia, sendo transparente no livro A função do orgasmo (1975), seu discurso sobre a sexualidade se vincula à condição sócio-econômica. Assim, quando diz que "as enfermidades psíquicas são a conseqüência do caos sexual da sociedade" (p. 14), refere-se à forma como esse caos atende aos interesses dominantes de subjugar psicologicamente os indivíduos a uma sociedade hierárquica, autoritária e mecanizada.

Com isso, Reich considera que a supressão da sexualidade natural gera uma ânsia de prazer que, expressa-se fisiologicamente através de espasmos musculares crônicos - que denominou couraça. É esta ânsia, diz ele, que é o cerne do medo, que aprisiona homens e mulheres, que os fazem sujeitarem-se a indivíduos ou grupos. Medo de ter uma vida independente orientada para a liberdade. Medo que serve de alicerce para a produção de ditadores, e que é transmitido de geração para geração.

Sabe-se que todo organismo vivo expressa-se em movimentos. Porém, esse processo de expressão pode sofrer inúmeras alterações. Cada movimento revela um estado biológico e emocional do protoplasma. Um indivíduo encouraçado, por exemplo, se manifes- ta de inúmeras maneiras: de forma constrangida, como se estivesse a se esconder; de forma expansiva simulando uma fluidez que de fato não existe.

O processo de encouraçamento não é consciente, nem tampouco seu estado - uma pessoa não tem consciência de sua couraça como tal, mas sim do seu reflexo, que se dá através de suas percepções internas:

\footnotetext{
"Descreve-se como apática, rígida, limitada, vazia ou queixa-se de palpitações, prisão de ventre, insônia, insatisfação nervosa, náusea, etc. Se a blindagem ${ }^{2}$ existe a muito tempo e também fez efeito nos tecidos dos órgãos o doente procura-nos por causa de úlceras pépticas, reumatismos, artrite, cancro ou angina de peito" (Reich ,1989. p.434).
}

$\mathrm{Na}$ terapia reichiana toda somatização, desconforto físico ou emocional são traduzidos em couraça. Outra característica importante do organismo encouraçado é sua incapacidade de exprimir seus sentimentos de forma autêntica.

\begin{abstract}
"É incapaz de dar livre curso à raiva ou de bater com o punho numa imitação de raiva" (...) "Não é capaz de mover a pelve para a frente. Quando lhe pedem para o fazer, uma pessoa blindada muitas vezes não compreenderá o que lhe pedem ou fará um movimento errado, isto é, um movimento indicativo de retraimento" (Reich,1989. p.434).
\end{abstract}

Essa reflexão é essencial para que se compreenda a couraça, que Gaiarsa (1984) define como todo o esforço de carga e contenção que dispendemos a fim de controlar a fluidez dos movimentos. É o dispositivo que transforma fluência em estrutura. Isto é, um conjunto de tensões musculares crônicas inutilmente mantidas, porque, para que se entenda o processo de encouraçamento, há de se ter em vista a existência de dois tipos de couraça: uma primeira, que caracteriza-se por contrações musculares temporárias ou voluntárias e que manifestam-se em qualquer animal vivo quando ameaçado, mas que são deixadas de lado assim que a ameaça desaparece. E uma segunda, onde as contrações musculares são de caráter permanente ou crônico. Esta última, nasce da mesma fonte da anterior, porém agora a ameaça é constante, exigindo que as defesas estejam sempre presentes, tornandose crônicas (Baker, 1980).

Trotta (1993) denomina essas couraças 
respectivamente como couraça funcional e couraça estrutural, sendo que neste estudo nos referiremos a este último tipo, que cronificam-se de tal forma que, mesmo mais tarde quando desnecessária já não consegue mais desfazer-se.

Gaiarsa (1984) afirma que, se confrontarmos a pobreza real de movimentos da grande maioria das pessoas com toda riqueza que elas poderiam ter, a diferença será espantosa. A grosso modo, isso deve-se às couraças, que nos impedem de fazer os gestos e movimentos que queremos, desejamos ou precisamos fazer; e que impediram no passado que fizéssemos os gestos que nos convinham.

É fundamental que se entenda que o potencial patogênico não vem do conflito psíquico, e sim da emoção reprimida nele. Por isso não é suficiente ao indivíduo entender racionalmente o seu conflito, a não ser que consiga deflagrar os afetos associados. Sendo este motivo das emoções serem a questão-chave da abordagem reichiana.

Quanto mais Reich avançava na análise das defesas do caráter $^{3}$, mais descobria que toda pessoa neurótica que tratava se achava perturbada enquanto um organismo total, e consequentemente deveria ser tratada sob esta perspectiva (Boadella, 1985).

Tendo isso em vista, desenvolveu sua abordagem conciliando técnicas de intervenção terapêutica tanto verbal - que fundamenta-se na Análise do Caráter, criada por Reich tendo por base os pressupostos da psicanálise - quanto corporais - pois o organismo vivo tem uma infinidade de formas de expressar seus sentimentos que não apenas a linguagem falada.

Na prática são utilizados trabalhos que incluem movimentos desbloqueantes (actings) e expressivos, massagens, exercícios de relaxamento e de respiração, posturas fixas e estimulações sensoriais, trabalhos sobre os reflexos fisiológicos e sobre a relação estabelecida através do vínculo cliente/ terapeuta. Entretanto, estas técnicas não são fixas e sistemáticas devido às especificidades de cada indivíduo, e que podem ser caracterizadas como (1) hipo ou hiperorgonóticos, na medida em que estão respectivamente com menor ou maior carga orgonótica ${ }^{4}$ no organis-

mo. Ou ainda; (2) pelo seu traço de caráter que nunca é "puro". Na verdade somos uma união de todos eles, sendo que há sempre aquele que é dominante na psicodinâmica do sujeito, e que deverá ser norteador no seu processo de desencouraçamento.

Contudo, a metodologia utilizada encerra uma certa lógica, iniciando-se pelos primeiros segmentos e progressivamente avançando para os últimos, ou seja, obedece a seqüência do desenvolvimento ontogenético (encéfalocaudal e próximo-distal). Entretanto, Trotta esclarece que esta regra não é seguida de forma rígida, pois trabalhamos sobre um sistema de vida integrada e não será coerente seguirmos uma regra de maneira mecânica, segmento após segmento.

No início, o tratamento dá-se em função do desencouraçamento segmentar; a medida que este processo alcança seu objetivo, passa-se para a fase final da terapia, que consta de uma mobilização simultânea sobre vários segmentos e estimulação da respiração profunda, com o objetivo de aumentar a carga energética no corpo e finalmente recuperar o reflexo do orgasmo ${ }^{3 / 4}$ objetivo final da terapia reichiana ${ }^{3 / 4}$ onde o indivíduo tem uma descarga energética, com convulsões por todo o corpo, semelhantes ao momento do orgasmo. Para alcançar esse nível de entrega é necessário um desbloqueio tal para que o organismo não se encontre mais segmentado e sim coeso em sua unidade física e emocional.

\begin{abstract}
"Potência orgástica é a capacidade de abandonar-se, livre de quaisquer inibições, ao fluxo de energia biológica; a capacidade de descarregar completamente a excitação sexual reprimida por meio de involuntários e agradáveis convulsões do corpo" (Reich,1975. p.92).
\end{abstract}

Na concepção reichiana o reflexo do orgasmo é buscado como uma manifestação do ciclo vital: carga-tensão/descarga-relaxamento, isto é, tudo na vida é um movimento de carga e tensão, onde se reúne força para ir de encontro aos desejos (seja no trabalho, nas diversas relações, no lazer, etc.) - seguido do movimento descarga relaxamento, onde gozase a conquista e a vivência. Esta é a lei que rege a vida, se não a obedecemos, se fazemos o que não desejamos ou nos colocamos em situação de stress excessivo, devemos isto à couraça.

Em síntese, a abordagem reichiana tem

"Na
concepção
reichiana o ser
humano é uma
unidade
biopsíquica cujo
funcionamento é
expresso
simultaneamente
em emoções e
funções
fisiológicas. As
contençães
emocionais
associadas aos
impulsos instintos
privados de
satisfação
cronificam-se
perturbando o
funcionamento
orgânico e
psicológico; sendo
esta a origem de
todas as
patologias.

"Na
concepção reichiana o ser humano é uma unidade biopsíquica cujo funcionamento é expresso simultaneamente em emoções e funções fisiológicas. $A$ contenções emocionais associadas aos impulsos instintos privados de satisfação cronificam-se perturbando o funcionamento orgânico e psicológico; sendo todas as patologias." 
por objetivo o desencouraçamento, ou seja, desfazer traços da psicodinâmica do sujeito que limitam sua expressividade física e emocional.

\section{METODOLOGIA ADOTADA NO PROCESSO INVESTIGATÓRIO}

Analisando os enfoques teóricos dos paradigmas que vêm sendo utilizados nas investigações educativas (positivista, interpretativo e sócio-crítico) e, considerando o contexto no qual foi realizada as observações do estudo, optamos em adotar o paradigma de

"A Psicanálise e a economia sexual tomaram direções opostas, uma vez que a primeira passou a não dar atenção à quantidade emocional e a se concentrar cada vez mais nos conteúdos da vida psíquica e a se desenvolver em direção a uma psicologia das idéias; enquanto que o foco de Reich na quantidade de excitação deveria levá-lo ao campo da pesquisa da energia física" perspectiva humanístico-interpretativa.

Na opinião de Arnal e outros (1992), este paradigma apresenta um maior risco de subjetividade e imprecisão nos resultados, sem que por isso tenhamos que renunciar ao seu estudo. Portanto, tendo consciência das desvantagens apontadas, o estudo foi realizado dentro desta perspectiva, considerando as limitações que um estudo desta natureza possa ter em termos de generalizações, isto é, de transferibilidade, embora os dados conclusivos que apresentamos não tenham esta finalidade.

Dentro de uma perspectiva humanísticointerpretativa, a investigação caracterizou-se como sendo um estudo descriti-vo-exploratório, uma vez que se propõe verificar finalidades e estruturas metodológicas de cada prática observada; ação e interação do facilitador e interpretação do significado atribuído a cada prática pelos participantes.

A observação foi o instrumento uti- lizado na coleta das informações. Quatro foram os grupos observados, ou seja, grupos de Antiginástica, de Biodança, de Formação Pessoal e de Terapia Reichiana. Além das anotações realizadas durante as observações, realizou-se entrevistas com alguns praticantes e com professores-facilitadores. Os praticantes entrevistados foram selecionados aleatoriamente. Os professores-facilitadores permitiram e facilitaram a coleta das informações, que apresentamos como dados conclusivos do estudo.

Antes de passar à descrição e análise das informações, queremos registrar que durante todo processo investigatório tínhamos consciência que o estudo realizado se constitui um exercício de investigação sem a pretensão de generalizar as inferências conclusivas, mas sim de contextualizá-las.

\section{DESCRIÇÃO E ANALISE DA COLETA DAS INFORMAÇÕES}

As informações recolhidas no estudo levado a cabo engloba observações e entrevistas com facilitadores-professores e praticantes das quatro práticas corporais alternativas, isto é, Antiginástica, Biodança, Formação Pessoal e Terapia Reichiana. Em continuação, apresentamos a síntese do quadro geral das observações realizadas no decorrer do processo investigatório.

O estudo englobou observações de 41 sessões, totalizando 83 horas de observações, acrescidas das 18 entrevistas com praticantes e facilitadores conforme especificação no quadro geral. A duração das sessão foi variada,

Quadro Geral das Observações

\begin{tabular}{|l|c|c|cc|}
\hline Prática observada & $N^{\circ}$ de sessões & $\begin{array}{c}\text { Tempo observado } \\
\text { em minutos }\end{array}$ & $\begin{array}{c}\text { Entrevista com pacientes } \\
\text { e facilitadores }\end{array}$ \\
\hline Antiginástica & 10 & 600 & - & 1 \\
\hline Biodança & 09 & 1.620 & 4 & 4 \\
\hline Formação pessoal & 12 & 2.160 & 3 & 1 \\
\hline Terapia ocupacional & 10 & 600 & 5 & - \\
\hline TOTAIS & 41 & 4.980 & 12 & 6 \\
\hline
\end{tabular}


sendo a menor de 60 minutos e a maior de 180 minutos.

Com a finalidade de ir ao encontro dos objetivos do estudo, passamos a descrever e analisar cada uma das práticas corporais observadas.

\section{Antiginástica}

O trabalho nesta prática era dirigido por uma fisioterapeuta, ocorrendo as aulas em um consultório - sala espaçosa, acarpetada, bem arejada, com colchonetes e demais materiais necessários ao trabalho. A freqüência semanal das sessões era de 120 minutos, divididas em duas sessões de 60 minutos cada, sendo que era oferecido um terceiro horário, também de 60 minutos, para aqueles alunos que desejassem fazer mais aulas ou que faltassem em uma das duas primeiras.

A operacionalização das sessões segue a seguinte rotina:

Primeiro momento: normalmente os alunos chegam uns cinco minutos antes de iniciar a sessão. Conversam livremente, raramente entrando em questões pessoais.

Falavam com a facilitadora (responsável pela direção da sessão), sem nenhuma formalidade, de como tinham passado. Caso referissem alguma dor ou tensão, na medida do possível, ela orientava-os com algumas alternativas para saírem do referido quadro.

Segundo momento: os alunos são convidados a escolherem seus lugares na sala, para começar a sessão propriamente dita. A primeira tarefa solicitada aos alunos é que perceba seu pé, o contato deste com o chão, pois no entender da facilitadora, isso é básico para que a pessoa comece a trabalhar toda a sua estrutura corporal.

Após isso feito, passa-se a trabalhar com alongamentos, automassagem, exercícios de respiração e outros movimentos. Sendo que, o que caracteriza esses trabalhos é que os mesmos são realizados lentamente, num tempo relativamente longo. Muitas vezes a facilitadora também os executa, explicando e demonstrando-os. Sempre atenta à execução, corrige quando alguém assume uma posição prejudicial à postura, sem ensinar a forma mais ou menos correta de fazer, delegando sempre ao aluno que descubra a forma como tomará consciência do que está fazendo.

Terceiro momento: ao final dos exercícios é sempre proposto ao aluno que deite-se no colchonete, relaxe e perceba como está se sentindo. Orienta-se para a importância de alongar-se antes de levantar.

\section{Relato das observações}

$\mathrm{Na}$ conversa informal com a facilitadora ela nos diz que as pessoas que buscam o seu trabalho têm duas peculiaridades: em primeiro lugar não querem a dinâmica das academias de ginástica, desejando um trabalho mais calmo, mais relaxante, e em segundo lugar, sofrem de lesões músculo-esqueléticas, tensão, stress, etc, percebendo em sua abordagem a possibilidade de alívio ou resolução desses problemas através da proposta alternativa.

Outro ponto na proposta da prática que relatamos, diz respeito à abordagem do indivíduo como um todo. Sempre esclarece aos alunos que não tratará somente o local que está sendo alvo de queixa naquele momento, pois se um músculo está lesado, os outros estarão sendo sobrecarregados. Objetiva com isso deixar claro que o trabalho não será dirigido exclusivamente para a lesão, apesar de que esta não será perdida de vista. Diferente de Bertherat, não houve nas sessões observadas um espaço explícito delegado a fala, ela não é proibida, porém também não é estimulada, buscada como parte do processo terapêutico e grupai. Uma única vez durante as sessões percebe-se uma aluna desabafar seus problemas, mas isto não ocorreu durante a sessão, e sim em conversa informal antes do início. Os próprios alunos, ao chegar, limitam-se a conversar o trivial.

Pode-se dizer que, quando a facilitadora observada define sua abordagem como Antiginástica, está na verdade apontando sua perspectiva de trabalho como entende as doenças e deformações físicas, de que forma trata seus pacientes e que postura assume consigo mesma.

\section{Biodança}

Foram acompanhados dois grupos de Biodança durante o processo investigatório. A

\section{"Descreve-se como apática, rígida, limitada, vazia ou queixa-se de palpitações, prisão de ventre, insônia, insatis- fação nervosa, náusea, etc Se a blindagem $^{2}$ existe a muito tempo e também fez efeito nos tecidos dos órgãos o doente procura-nos por causa de úlceras pépticas, reuma- tismos, artrite, cancro ou angina de peito."}


coleta das informações nesta prática foi feita através da observação participante, uma vez que não é aceito que alguém fique observando "passivamente" as sessões.

Em geral as sessões de Biodança observadas duravam em tomo de 180 minutos, com um encontro semanal, com a seguinte dinâmica:

Primeiro momento: as pessoas começam a chegar e ficam conversando e "brincando" livremente por quase 60 minutos.

Segundo momento: o facilitador chama os alunos para fazer uma grande roda, sentados no chão. Quando tem um aluno novo, to-
"É incapaz de dar livre curso à raiva ou de bater com o punho numa imitação de raiva" (...) "Não é capaz de mover a pelve para a frente. Quando lhe pedem para o fazer, uma pessoa blindada muitas vezes não compreenderá o que lhe pedem ou fará um movimento errado, isto é, um movimento indicativo de retraimento." dos se apresentam, o habitual é pegar na mão do companheiro ao lado para passar-lhe a vez na apresentação.

Nesse momento o facilitador retoma alguns pontos da última aula, onde então todos têm a liberdade de falar sobre suas impressões e sensações da aula anterior.

Este também é momento das informações e recados, por parte de qualquer elemento do grupo, ao grande grupo.

Terceiro momento: todos ficam descalços e são convidados a iniciar a vivência, que dura de 80 a 100 minutos. Esse momento estava assim assim dividido:

1. Parte inicial: As vivências iniciam normalmente de duas formas : (1) todos de mãos dadas formam uma roda e caminham juntos ao som de uma música ${ }^{5}$; ou (2) inicia-se andando sozinho ou a dois, para entrar em sintonia com o andar do outro (com ou sem música);

2. Parte principal: aqui será dado ênfase às cinco linhas de vivência (vitalidade, criatividade, afetividade, sexualidade e transcendência), podendo-se trabalhar todas em uma mesma aula, ou enfatizando-se o trabalho sobre duas ou três apenas. Isso dependerá do grupo e dos objetivos do facilitador para com este.

A cada exercício proposto durante a sessão, o facilitador dá uma pausa onde demonstra o que quer que seja feito e fala do objetivo e da importância do trabalho. Ao final de cada um desses exercícios, as pessoas que fizeram juntas, abraçam-se e despedem-se, antes de passar para a próxima vivência, que normalmente será com outra pessoa. Isso não significa que não se pode continuar com a mesma dupla, porém se isso perdura por muito tempo, o facilitador propõe que procurem trocar os pares ou trios para não se formar pequenos grupos dentro do grande grupo.

Quanto às vivências em si, eram envolventes ora pelo prazer, ora pelo desconforto que suscitavam, situação essa bastante individual, que fazia com que num mesmo exercício, algumas pessoas não conseguissem participar, por vezes se afastando ou chorando, enquanto outras mostravam em gestos e palavras um gosto por estar vivenciando-as.

Nesse sentido, quando as pessoas se sentem mal ou se isolam durante a sessão, o facilitador procura ser o continente, ora aproximando-se delas, ora deixando que a própria pessoa lide com suas dificuldades.

3. Parte final ou volta à calma: algumas vezes as sessões eram finalizadas com uma "roda de despedida", como é denominado pela facilitadora, ou com qualquer outra dinâmica de confraternização, onde os participantes são convidados a se despedirem uns dos outros com um gesto, um abraço, etc .

\section{Relato das observações}

Em uma das sessões, um participante relatou que antes de iniciar a prática da Biodança se sentia muito solitário. De fato, observou-se que as pessoas se procuravam, saiam juntas e faziam programas fora do espaço de trabalho. Aliás, nesse sentido, não apenas os grupos observados, mas os Biodanceiros, como se costuma chamá-los, promovem festas entre eles e procuram se conhecer melhor e estreitar relações.

Em contraponto, percebeu-se que esta aproximação acaba sendo terreno fértil para que muitos dos relatos de desagrado e mal-estar que alguém possa ter para com o grupo ou com algum elemento, não sejam exteriorizados no grande grupo. Mesmo que se diga que é necessário respeitar a disponibilidade e o ritmo de cada um, há momentos em que esse tipo de argumentação pode estar camuflando situações difíceis de se lidar, às quais as pessoas, não se propondo a certificarem-se sobre o que 
está ocorrendo, tangenciam tais questões. Citamos abaixo, a título de ilustração, alguns relatos ouvidos em conversas informais:

- "Na última aula fiquei na frente da casa vendo vocês entrarem, não consegui entrar também ... chorei na sombra de uma árvore e fui embora ..." (é comum esta pessoa não participar de algumas vivências, se excluindo - pessoa com um ano e meio de vivências nesta prática);

- "Me sinto mal ao me expor ao grande grupo"(aluno a um ano nesta prática);

- "Não gosto de fulano" (aluna com três meses de Biodança);

- "Me incomoda a forma como as pessoas se olham aqui, principalmente quando são as mulheres ..." (aluna com três meses de Biodança).

Chamamos a atenção para esta questão porque estas coisas jamais eram verbalizadas no grupo, ao mesmo tempo que percebemos muitas pessoas tencionadas durante as vivências. Ocorre que, criar situações vivenciais que fazem emergir pensamentos e emoções e não provocar relatos e análises mais profundas, pode ser tão dissociativo quanto ficar elucubrando a respeito do que se sente.

\section{Formação pessoal}

As sessões de Formação Pessoal observadas se realizavam em uma sala de ginástica olímpica, onde havia tatames, sobre os quais eram feitas as vivências.

As sessões faziam parte de uma disciplina do Curso de Mestrado em Ciências do Movimento Humano, onde os investigadores atuaram como observador-participante e como facilitador, onde a freqüência era de um encontro por semana de aproximadamente 120 minutos e as sessões obedeciam a seguinte seqüência:

Primeiro momento: no início da sessão os alunos são estimulados a falar alguma coisa referente à última sessão. Coisas que ainda não relataram e que gostariam de dizer naquele momento. Antes de iniciar a sessão propriamente dita, o facilitador explica ao grupo as atividades que serão realizadas. Neste momento, todos ficam sentados em círculo e descalços. Momento que é denominado de Ritual de Entrada.
Segundo momento: são propostos trabalhos corporais aos quais a participação fica a critério de cada aluno, entretanto eram raras as vezes que alguém não participava.

As vivências constam de dois outros momentos bem configurados. Por um lado, atividades que variam de uma sessão a outra, ora individuais, ora em pequenos grupos, de caracter lúdico e cooperativas. Os jogos competitivos são substituídos por jogos cooperativos. Nesta prática o facilitador estimula os participantes a realizar atividades sem o auxílio da visão (com venda nos olhos).

Por outro lado, atividades de sensibilização que são realizadas em duplas, ora utilizando algum instrumento como mediador entre um corpo e outro (bola, corda, bastões, etc), ora em contato corporal direto. Tanto em um momento como em outro, a música faz parte do cenário como elemento propulsor das emoções. O facilitador utiliza como recurso pedagógico a troca permanente dos pares, fazendo com que cada indivíduo tenha que vivenciar as atividades com todos os elementos do grupo.

Nas sessões em que o trabalho final proposto se realiza em duplas, é sugerido que as duplas conversem sobre as vivências, isto é, que cada um fale para o outro como se sentiu, procurando não mascarar seus desconfortos.

Terceiro momento: os participantes faziam registro das emoções vivenciadas, ou seja, o facilitador propõe que cada participante escreva aquilo que entender relevante sobre o que foi vivenciado. A técnica utilizada tem a finalidade de garantir a fidedignidade dos sentimentos, emoções, etc, que irá facilitar a elaboração do memorial descritivo final, tarefa que todos os participantes deverão realizar no final do curso (memorial descritivo das vivências).

Quarto momento: a última parte da sessão é denominada de Ritual de Saída, momento em que o facilitador oportuniza cada participante a falar de si, isto é, como sentiu as vivências, sem entrar em julgamento de mérito sobre as tarefas propostas. Este é um momento de verbalização para cada um dizer o que quer, desde que fale de si. O facilitador adota uma posição de escuta, sem julgamentos ou apartes.

\section{"Potência orgástica é a capacidade de abandonar-se,} livre de quaisquer inibições, ao fluxo de energia biológica; a capacidade de descarregar completamente a excitação sexual reprimida por meio de involuntários $e$ agradáveis convulsões do corpo." 
Como se tratava de um curso de mestrado, a sessão não era composta apenas de vivências. Havia sempre um momento em que se discutia algum texto, cujo conteúdo permitia que os participantes fizessem algumas reflexões sobre a prática.

\section{Relato das observações}

Relatamos as observações tendo em vista os objetivos básicos da Formação Pessoal. Esta abordagem é um espaço onde, através das vivências e do estímulo à verbalização, é oportunizado ao sujeito utilizá-la como via de expressão e comunicação. Dentro deste quadro é freqüente ouvir um aluno falar de si, suas dificuldades e facilidades, de recordações que havia esquecido ou mesmo de como se sente naquele momento. Destacamos alguns relatos verbalizados pelos participantes desta prática:

autoconhecimento , ou seja, tenho conhecimento das causas das dores $e$ rompo com isso. Não aturo mais viver um longo prazo com situações

desconfortantes, criei uma percepção e sinto quando não estou legal e tomo outro rumo, que me dê mais prazer. Eu já vejo isso, tenho um sinal de alerta que se instalou, que me permite corrigir o rumo".
- "De olhos abertos acabo trabalhando sempre com as mesmas pessoas e com os olhos fechados nunca se sabe quem é, e isto faz com que eu me sinta bem";

- "De olhos vendados no início eu sentia muita angústia, queria saber quem estava comigo, mas agora não ligo mais para isso";

- "Me percebi extremamente contido no trabalho em dupla";

- "Pintei o que estou buscando hoje: o crepúsculo do sol, os pássaros, o movimento, a natureza ..." (trabalho que consiste em fazer a máscara que gostaria no rosto do outro, utilizando cremes coloridos);

- "Na técnica sobre o relato da infância, fiquei impressionada de ter lembrado da casa queimada ... Porque nunca falei isso para ninguém, acho que nem para o meu marido".

Os relatos dos participantes eram feitos no grande grupo e sempre ocorriam no ritual de saída, momento em que o professorfacilitador oportuniza que cada um fale de si, de como se sentiu naquela vivência. Neste momento não se permite julgamento de mérito sobre o que foi proposto, mas sim, relatar aquilo que se permite dizer de si no grande grupo. O professor-facilitador apenas escuta, não intervém, oportuniza a exteriorização dos sentimentos e das emoções.

Após o ritual de saída, costumava-se discutir textos que o professor indicava previamente, todos relacionados a corporeidade. Neste momento, as pessoas passavam a falar de si e de sua postura profissional. No debate, muitas vezes os ânimos "esquentavam" e alguns pontos de vista eram divergentes. Nesse caso, o professor intervinha em alguns momentos até que dava-se um fechamento, sendo sistematicamente proposto um outro tema para o encontro seguinte. Era uma forma de alimentar o grupo de subsídios teóricos que auxiliassem na compreensão do vivenciado.

Destacamos criteriosamente alguns relatos ouvidos nos debates:

"Foi ótimo, agora passo a entender como é importante vivenciar um trabalho como este antes de propor aos alunos";

"A diferença entre esta e outras práticas corporais que eu já vivenciei, é que nesta não há preocupação de responder a um modelo predeterminado, mas sim de realizar as atividades de forma espontânea."

Os relatos tinham sempre um caráter individual, cada um dizia o que queria. Não havia interpretação do que ocorria nas sessões, cada um deveria buscar respostas às suas indagações, seja interpretando o que ouvia do grupo, seja através dos subsídios sugeridos nos textos e debatidos no grande grupo.

Contudo, dentre as razões que levam as pessoas a fazer esta vivência destacam-se: (1) a possibilidade de adquirir maior autoconhecimento; (2) a compreensão que é importante se trabalhar corporalmente antes de trabalhar o outro e, (3) a vontade de conhecer esta abordagem como uma abordagem corporal alternativa.

\section{Terapia reichiana}

As observações desta prática teve uma particularidade, tratava-se de uma abordagem terapêutica individualizada não sendo permitido observadores. Para incluí-la no estudo servimo-nos das anotações da autora deste trabalho, que por ter formação nesta técnica foi facilitadora e observadora ao mesmo tempo. Isto de certa forma, constitui-se uma limitação do estudo.

O trabalho foi levado a cabo em con- 
sultório particular. A freqüência das sessões foi de uma sessão semanal com duração de 60 minutos (embora se possa realizar mais de uma sessão por semana).

A dinâmica das sessões seguiu o seguinte itinerário:

Primeiro momento: o participante verbaliza neste momento como se encontra ou qualquer assunto de seu interesse.

Segundo momento: a partir do que foi exposto no primeiro momento, existem dois encaminhamentos básicos: (1) caso traga algum assunto emergente ${ }^{6}$, fica-se no campo verbal o tempo necessário dentro do horário terapêutico para trabalharmos o assunto em questão, ou propõe-se alguma vivência que de alguma forma se vincule às suas necessidades ou; (2) se por outro lado, não há assunto que se considere relevante, passa-se a dar ênfase ao seu estrutural ${ }^{7}$, através de propostas que podem ser, predominantemente, verbal ou vivencial. Dependendo do trabalho proposto, o facilitador participa ativamente ou observa, acompanhando o cliente e, se necessário, intervém.

Ao final de cada vivência, certifica-se de como o paciente está. Avalia-se o que lhe aconteceu, o que sentiu, quais pensamentos the ocorreram, etc.

Terceiro momento: ao final da sessão procura-se dar um fechamento ao trabalho, que pode ser um relaxamento, ou interpretação desde a perspectiva reichiana do que foi vivenciado, uma espécie de feedback do que se passou. Na verdade o procedimento neste momento, oscila muito de um cliente para outro e de uma sessão para outra.

\section{Relato das observações}

Esta prática trabalha com um referencial psicossomático, que vai além do simples olhar não dicotômico sobre o homem. Em tese, avança na medida que apresenta uma metodologia específica de intervenção que atua sobre a biodinâmica das emoções. As pessoas que o procuram, buscam trabalhar e avaliar profundamente sua dinâmica de vida, delegando ao terapeuta o direito de tocá-lo, interpretá-lo, apontar suas contradições, deflagrar emoções,

propor-lhe que faça exercícios ou assuma determinadas posturas, etc.

Descrevemos alguns relatos que registramos no decorrer desta prática:

\begin{abstract}
"Esse trabalho não permite que nos escondamos atrás do discurso, o exercício acaba mexendo e trazendo coisas profundas" (participante com oito meses de terapia);
\end{abstract}

"As outras (práticas corporais que já vivenciou)
eram só exercícios físicos, não mexiam com os
sentimentos e emoções nem traziam isso à tona,
como na reichiana, que mexendo o corpo traz coi-
sas internas, profundas, que faz emergir o
inconsciente"(participante com dez meses de te-
rapia).

O terapeuta reichiano trabalha sobre as representações psíquicas e emocionais e sobre os correspondentes corporais destas representações no sujeito. Este, por sua vez, entra no processo tendo consciência disso e delegando esse poder ao terapeuta, para juntos provocarem transformações na sua vida.

Sendo assim, do ponto de vista corporal, o objetivo é desfazer as couraças ${ }^{3 / 4}$ representações físicas dos desvios emocionais ${ }^{3 / 4}$ e do ponto de vista emocional é fazer a análise caracterológica ${ }^{34}$ que objetiva tratar o traço de caráter do sujeito, que da mesma forma, reverter-se-á em abrandamento das couraças. lata:

Um praticante após algumas sessões re-

"O significado que hoje dou à terapia dá para sin-
tetizar no seguinte: autoconhecimento, ou seja,
tenho conhecimento das causas das dores e rom-
po com isso. Não aturo mais viver um longo pra-
zo com situações desconfortantes, criei uma
percepção e sinto quando não estou legal e tomo
outro rumo, que me dê mais prazer. Eu já vejo
isso, tenho um sinal de alerta que se instalou, que
me permite corrigir o rumo".

Quando diz isso, refere-se ao fato de dar-se conta de quando está indo além de seu limite, estressando-se e agredindo-se, causando mal-estar e dor. Nesse momento, ao ouvirse, respeita seu ritmo e muda de atitude. Com esse funcionamento tem alcançado melhora e pode até decidir terminar o processo terapêutico, desejo que será respeitado pelo terapeuta.
"Acredito que ocupam um lugar intermediário entre formas tradicionais de exercitar o corpo (ou manter a linha)" (...) "e as $T C^{*}$ propriamente ditas. Distanciamse das formas tradicionais por seu repúdio à simples manutenção da forma física e à preocupação puramente estética. Aproximando-se das TC por sua ênfase em noções como 'consciência corporal', 'energia', 'espontaneidade', 'repressãa' entre outras. Por outro lado, os profissionais que criam estas práticas corporais ou a elas se dedicam costumam ser exbailarinos, exatores, fisioterapeutas ou mesmo professores de ginástica e mais raramente psicólogos ou médicos." 
DISCUSSÃO E INTERPRETAÇÃO DAS INFORMAÇÕES

\section{— Pontos de encontro e divergência -}

A tarefa a que nos propomos poderá ser bem mais extensa, de forma que não pensamos esgotá-la. Entretanto, selecionamos alguns pontos de encontro e de divergência entre as práticas corporais alternativas estudadas.

\footnotetext{
"O conjunto das reações inconscientes do analista à pessoa do analisando e mais particularmente à transferência deste" (...)

"Freud... vê nela o resultado da 'influência do doente sobre sentimentos inconscientes do médico' e sublinha que 'nenhum analista vai mais longe do que os seus próprios complexos e resistências internas lhe permitem', o que tem como corolário a necessidade de o analista se submeter a uma análise pessoal."
}

Antes, porém, gostaríamos de apontar que ao longo deste estudo foi se explicitando dois campos de abordagens corporais distintas, às quais recorremos a Russo (1993), que traduz muito bem o que vamos referir, ao definir de forma diferenciada as práticas corporais das terapias corporais. Conceitua as primeiras como não curativas, na medida em que não se denominam como um tratamento, referindo-se a estas da seguinte forma:

"Acredito que ocupam um lugar intermediário
entre formas tradicionais de exercitar o corpo
(ou manter a linha)" (...) "e as TC* propriamente
ditas. Distanciam-se das formas tradicionais por
seu repúdio à simples manutenção da forma
física e à preocupação puramente estética.
Aproximando-se das TC por sua ênfase em
noções como 'consciência corporal', 'energia',
'espontaneidade', 'repressão' entre outras. Por
outro lado, os profissionais que criam estas
práticas corporais ou a elas se dedicam costu-
mam ser ex-bailarinos, ex-atores, fisioterapeu-
tas ou mesmo professores de ginástica e mais
raramente psicólogos ou médicos" (Russo,1993.
p.117).

Russo inclui nesse espectro a Biodança e a Antiginástica, sendo que acrescentamos a Formação Pessoal, vista neste trabalho como pertencente a este enfoque.

Em contraponto, o autor define as terapias corporais como "um conjunto mais ou menos homogêneo" (p.l 17), por ser comum terem Reich e sua teoria como pólo norteador.

Queremos, portanto, dizer que estas linhas limítrofes não ficam claras, quando tratamos de questões mais genéricas no leque de interpretações possíveis entre estas abordagens, tais como a importância dada em todas elas a uma perspectiva integrada de homem, seja quando (1) Bertherat diz que nossa história de vida se expressa tanto nas linhas de nos- so corpo, como em nossa dinâmica psíquica; ou (2) quando Toro aponta a urgência de unificar o indivíduo, e entender que corpo e alma são dois aspectos de uma mesma realidade; ou (3) quando Lapierre e Aucouturier buscam avançar em sua prática psicomotriz indo de encontro a uma leitura mais afetiva e psicológica, além de corporal de seus alunos e, por último, (4) quando Reich afirma que o homem é uma unidade psicossomática.

Ocorre que ao discutir o corpo discutimos o homem em suas condições físicas, psicológicas e espirituais, sua cultura e sociedade na qual está inserido, enfim lhe lançamos um olhar que até dissocia ao dizer, como o faço agora, mas já não pode mais dissociar ao perceber e ao vivenciar, como buscam fazer as abordagens corporais acima. Pois todas elas têm uma leitura sobre o sujeito que, ao negar a dualidade corpo/mente, para Russo (1993), "psicologizam" as práticas corporais e "somatizam" as teorias psíquicas.

Outro ponto comum a todas as abordagens aqui estudadas é o que se refere à proposta de que a formação dos profissionais das diferentes técnicas, passa também por uma formação de cunho pessoal, que significa dizer que estes devem se trabalhar corporalmente, desenvolver sua propriocepção e a consciência de si, para que assim, compreendendo suas variáveis subjetivas, tornem-se mais capacitados para trabalhar com as outras pessoas e, assim, ensiná-las a descobrir suas potencialidades.

Uma das preocupações básicas na formação do terapeuta reichiano, bem como em todas as psicoterapias, é que se tome consciência do "processo da contratransferência", definido por Laplanche como:

\begin{abstract}
"O conjunto das reações inconscientes do analista à pessoa do analisando e mais particularmente à transferência deste" (...) "Freud... vê nela o resultado da 'influência do doente sobre sentimentos inconscientes do médico' e sublinha que 'nenhum analista vai mais longe do que os seus próprios complexos e resistências internas lhe permitem', o que tem como corolário a necessidade de o analista se submeter a uma análise pessoal" (p.146).
\end{abstract}

Em suma, contratransferência são sentimentos e sensações que o paciente provoca no terapeuta e/ou que este último dedica àque- 
le. Para lidar com tais situações é necessário que o terapeuta tome consciência de tais questões, evitando deter-se em dificuldades subjetivas suas, pois pode implicar em perda na qualidade do tratamento, não promovendo a cura e o desenvolvimento terapêutico a que se propõe.

Entretanto, esta não é uma discussão que está presente apenas nas terapias corporais; nas práticas corporais já se preconiza a necessidade de se oportunizar ao professor e/ou facilitador, que vivencie sua expressividade corporal como um meio a mais que vai completar sua formação.

Talvez o ponto mais claro e polêmico, que esta abordagem levanta, seja permitir que o professor passe a ter mais disponibilidade corporal, conheça melhor suas limitações e, ao mesmo tempo, possa refletir sobre elas.

Este autoconhecimento permite o desbloqueio de certas resistências, permite uma dimensão mais real das limitações de cada indivíduo frente às diferentes situações e, consequentemente, prepara o profissional para ter uma postura de escuta em relação aos seus alunos, melhorando assim a compreensão e seu relacionamento com eles, evitando que caia no lugar comum da conduta ditatorial e repressora, sempre que se deparar com suas próprias dificuldades estampadas no outro.

Porém, a forma com que estas abordagens conduzem suas vivências se diferenciam bastante, podendo-se destacar o fato de, como já vimos, as práticas corporais não terem diretamente a cura como meta, mas sim proporcionar o autoconhecimento.

Para tanto, além das práticas corporais alternativas abrirem um espaço para a reflexão, onde a fala (verbalização) está presente como componente pedagógico, como no caso da Formação Pessoal, possibilitam vivências corporais variadas num clima de espontaneidade e descontração, onde os movimentos estereotipados propostos pelo professor não fazem parte da rotina.

Ainda dentro das peculiaridades referentes às práticas corporais e terapias corporais, as primeiras enfatizam o relaxamento, a sensibilização, apropriocepção, o alongamen- to, a expressividade, a criatividade, etc, enquanto as segundas buscam a catarse, a tomada de consciência associada às emoções aí vinculadas, como meio para o crescimento pessoal.

Percebemos que existe uma multiplicidade de motivações que leva as pessoas a procurar e se identificar com as práticas corporais alternativas que vão desde:

a) uma crença no grupo, no calor humano, no afeto, no contato, no respeito mútuo e possibilidade de resolução de problemas como solidão, inibição, dificuldades de relacionamento, como é o caso dos praticantes de Biodança;

b) o desejo de um espaço de introspeção e relaxamento, sem uma interação direta entre os componentes do grupo como é o caso dos praticantes da Antiginástica;

c) a necessidade de trabalharem a si próprios enquanto professores, refletirem sobre sua práxis, a partir de uma prática corporal que potência atividades lúdicas individuais e grupais e de sensibilização, sem a preocupação de responder a esteriótipos psicomotores previamente determinados, como é o caso dos praticantes da Formação Pessoal;

d) a perspectiva de mudança de comportamento através de uma elaboração que se dá no campo físico e psicológico simultaneamente, como é o caso dos praticantes da Terapia Reichiana.

Por tudo o que foi dito, fica claro que, apesar das diferenças nas formas de intervenção e em suas essências teóricas, tanto as práticas corporais como as terapias corporais, mesmo sendo denominadas a partir do referencial corpo ${ }^{3 / 4}$ que pode ser interpretado como dissociativo $^{3 / 4}$, tem muito presente uma percepção integrada do sujeito, compreendendo que o homem é um ser inconcluso e que ao perceber-se assim busca nas mais variadas alternativas uma complementaridade às suas ausências, sejam elas subjetivas ou objetivas, pois precisa constantemente rever seus conceitos e fazer uma auto-avaliação que deve, obviamente, estender-se aos profissionais destas áreas.

Deste modo, sem receio de estarmos sendo reducionistas, entendemos que as várias propostas de práticas corporais atendem a públicos específicos. Para cada corpo teórico haverá sujeitos que se identificarão e busca- 
rão vivenciá-los. Os interesses e as necessidades humanas são muitos, bem como as inúmeras abordagens terapêuticas existentes.

O que nos cria dúvidas e nos faz questionar, é o porquê estas e muitas outras práticas corporais são remetidas ao desprezo científico. Nos parece imperativo que sejam discutidas e tenham reconhecido seu valor social. Não é mais possível negar que muitas pessoas as procuram e se valem delas para crescimento pessoal.

Finalizando, no que diz respeito a uma alternativa metodológica viável à formação de professores e que complemente sua qualificação profissional, a hipótese que ocorre, a partir de tudo quanto foi visto até aqui, é de destacar a proposta de Formação Pessoal, não apenas porque várias são as abordagens que adotam tal perspectiva, mas também por compreender que é importante vivenciar e explorar as próprias potencialidades, refletir sobre sentimentos e comportamentos assumidos, enfim, aumentar o nível de autoconhecimento como pré-requisito para uma capacitação profissional mais ampla e consistente.

A Formação Pessoal como mais uma alternativa via de formação de professores, terapeutas, psicólogos e pedagogos em geral, não pretende ser uma formação acabada, mas sim uma formação permanente que oportunize vivências corporais freqüentes e um repensar continuado da capacidade de escuta da demanda do outro.

\section{CONCLUSÃO}

É significativo destacar o quanto as práticas corporais aqui apresentadas nascem da necessidade de resgatar um homem que viva suas diferentes dimensões - pensar, sentir e agir - de forma não reducionista, valorizando sua criatividade, sensações e percepções, remetendo-o a uma introspecção que lhe proporcione refletir e resignificar sua ação, não caindo no lugar comum do movimento repetitivo e mecanizado. Segundo estas práticas, a relação que o sujeito constrói com seu corpo é definitiva na construção de sua subjetividade, de tal forma que as pessoas procuram-nas com o desígnio de preencher hiatos que se formaram em sua vida pessoal e profissional.
É nesse aspecto que nos ocorrem algumas dúvidas como: seria possível ao espaço escolar amenizar o "elo perdido" na infância que origina a dissociação a que estão subjugados homens e mulheres? Até que ponto a proposta escolar pode e deve ser terapêutica? Talvez se pensarmos terapêutico, na medida em que "cura" o sujeito da ignorância de si mesmo, e da relação com seu corpo, oportunizando que este contate com suas potencialidades, desejos e emoções, podendo redimensionar suas possibilidades de vida, isso seja possível.

Entretanto, para que possamos mostrar o caminho ao outro, apoiando-nos em Bertherat, é preciso procurar o próprio caminho de volta para casa. Trata-se aqui de mais um ponto em comum entre estas práticas, e que diz respeito à formação dos formadores no que se refere à relação que estabelece com seu próprio corpo e com o corpo do outro, enfim, à construção da subjetividade do próprio professor, como um pressuposto para a sua capacitação profissional.

Sem dúvida, é preciso redimensionar os pressupostos com os quais trabalha a educação pela via corporal. Muitas são as propostas, mas aquelas que apontam para uma vivência que ressalte os sentimentos, emoções e capacidades do indivíduo e que leve-o a dar maior significado ao que faz, nos parece ser mais um caminho alternativo.

\section{REFERÊNCIAS BIBLIOGRÁFICAS}

BAKER, E. O labirinto humano: causas do bloqueio de energia sexual. São Paulo: Summus, 1980.

BERTHER AT, T. O corpo tem sua razões: antiginástica e consciência de si. São Paulo: Martins Fontes, 1986.

_. O correio do corpo: novas vias da antiginástica. São Pau lo: Martins Fontes, 1985.

_. As estações do corpo: aprenda a olhar o seu corpo para manter a forma. São Paulo: Martins Fontes, 1985.

_ . A toca do tigre. São Paulo: Martins Fontes, 1980.

BOADELLA, D. Nos caminhos de Reich. São Paulo: Summus, 1985.

GAIARSA, J.A. Couraça muscular do caracter. Wilhem Reich. São Paulo: Ágora, 1984.

LAPIERRE, A. ; AUCOUTUR1ER, B. Fantasmas corporais e a prática psicomotriz. São Paulo: Manole, 1985. 
LAPLANCHE, J.; PONTALIS, J.S. Vocabulário de psicanálise. São Paulo: Martins Fontes, 1985.

NAVARRO, F. Terapia Reichiana: fundamentos médicos somatopsicodinâmica. São Paulo: Summus, 1987.

NEGRINE, A. Aprendizagem e desenvolvimento infantil 3: psicomotricidade - perspectivas pedagógicas. Porto Alegre: Prodil, 1995.

_. A formação pessoal do adulto. Curso de Mestrado em Ciências do Movimento Humano. ESEF/UFRGS, 1994, 12 p.(texto).

RE1CH, W. A função do orgasmo. São Paulo: Círculo do Livro, 1975.

_ . Análise do caráter. São Paulo: Martins Fontes, 1972.

_ . A revolução sexual. São Paulo: Círculo do Livro, 1966.

RUSSO, J. O corpo contra a palavra: as terapias corporais no campo psicológico do anos 80. Rio de Janeiro : UFRJ, 1991

TORO, R. Teoria da Biodança - coletânea de textos. Fortaleza: ALAB, 1991.

TROTTA, E.E. Psicossomática reichiana e metodologia da organoterapia. Rio de Janeiro: Independente, 1993.

WINNICOTT, D. W. Realidad y juego. Barcelona: Gedisa, 1979.

\section{NOTAS}

${ }^{1}$ Entendem por fantasma uma produção imaginária inconsciente, isto é, capaz de motivar comportamentos sem que o indivíduo tenha destes consciência . "Assim,... só pode ser expresso através do simbólico" (1984, p.8).

2 "Blindagem" é a primeira denominação dada por Reich ao que mais tarde chamaria de couraça.

${ }^{3}$ Os traços de caracteres trabalhados na abordagem reichiana são: fálico, narcisista, histérico, masoquista, sádico, compulsi vo e oral.

4 "Orgonótica" vem de Orgônio, nome dado por Reich à ener gia geradora de vida presente na atmosfera e especialmente concentrada no organismo vivo.

${ }^{5}$ Este trabalho pode ser incrementado com outra dinâmica, dependendo da intenção do facilitador, tais como andar no ritmo da música, olhar no olho do outro, etc.

${ }^{6}$ Emergente: conflitos relacionados à vida atual.

${ }^{7}$ Estrutural: conflitos relacionados à história da vida pregressa do sujeito.

* A sigla TC é utilizada no texto de Russo (1993), substituindo a expressão "terapias corporais".

\section{UNITERMOS}

Antiginástica-biodança - formação pessoal terapia reichiana.

*Rosângela Fragoso é acadêmica do curso de licenciatura em Educação Física da UFRGS.

**Airton Negrine é Doutor em Filosofia da Ciência da Educação. Professor titular do Departamento de Ginástica e Recuperação da Escola de Educação Física da UFRGS. 